\title{
Correction to: Quantitative In-situ Analysis of Water Transport in Concrete Completed Using X-ray Computed Tomography
}

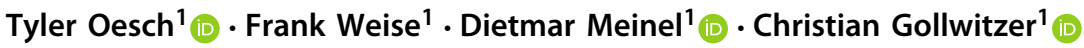

Published online: 23 January 2019

(c) The Author(s) 2019

\section{Correction to: Transport in Porous Media https://doi.org/10.1007/s11242-018-1197-9}

The article "Quantitative In-situ Analysis of Water Transport in Concrete Completed Using X-ray Computed Tomography", written by "Tyler Oesch, Frank Weise, Dietmar Meinel and Christian Gollwitzer", was originally published electronically on the publisher's internet portal https://link.springer.com/article/10.1007/s11242-018-1197-9 on 16 November 2018 without open access.

With the author(s)' decision to opt for Open Choice, the copyright of the article changed on 22 January 2019 to (C) The Author(s) 2018, and the article is forthwith distributed under the terms of the Creative Commons Attribution 4.0 International License (http://creativecommons.org/ licenses/by/4.0/), which permits use, duplication, adaptation, distribution and reproduction in any medium or format, as long as you give appropriate credit to the original author(s) and the source, provide a link to the Creative Commons license and indicate if changes were made.

The original article has been corrected.

Open Access This article is distributed under the terms of the Creative Commons Attribution 4.0 International License (http://creativecommons.org/licenses/by/4.0/), which permits unrestricted use, distribution, and reproduction in any medium, provided you give appropriate credit to the original author(s) and the source, provide a link to the Creative Commons license, and indicate if changes were made.

Publisher's Note Springer Nature remains neutral with regard to jurisdictional claims in published maps and institutional affiliations.

The original article can be found online at https://doi.org/10.1007/s11242-018-1197-9.

Tyler Oesch

tyler.oesch@bam.de

1 Bundesanstalt für Materialforschung und - prüfung (Federal Institute for Materials Research and Testing), Unter den Eichen 87, 12205 Berlin, Germany 